\title{
Genetic Diversity Analysis of Egyptian Native Chickens Using mtDNA D-loop Region
}

\author{
Ibrahim Elkhaiat ${ }^{1,4}$, Kotaro Kawabe ${ }^{2}$, Kamal Saleh ${ }^{1}$, Hassan Younis ${ }^{1}$, Reiad Nofal ${ }^{1}$, \\ Shinnya Masuda ${ }^{3}$, Takeshi Shimogiri ${ }^{4}$ and Shin Okamoto ${ }^{4}$ \\ ${ }^{1}$ Faculty of Agriculture, Kafrelsheikh University, Kafrelsheikh 33516, Egypt \\ ${ }^{2}$ Natural Science Centre for Research and Education, Kagoshima University, Kagoshima 890-0065, Japan \\ ${ }^{3}$ Liberal Arts Education Center, Aso Campus, Tokai University, Minami Aso-mura, Kumamoto 869-1404, Japan \\ ${ }^{4}$ Faculty of Agriculture, Kagoshima University, Kagoshima 890-0065, Japan
}

\begin{abstract}
This study was aimed to evaluate the genetic diversity of Egyptian native chickens by using mtDNA sequence polymorphism. A 546-bp fragment of the mtDNA D-loop region was sequenced for a total of 36 Egyptian native chickens with 14 reference sequences from DNA databank. Of the Egyptian chickens 5 haplotypes were identified. Haplotype diversity and nucleotide diversity of the Egyptian native chickens were $0.5635 \pm 0.0845$ and $0.00123 \pm$ 0.00108 , respectively. The Egyptian native chickens were distributed within one clade, which were closed to the haplotypes from Indian subcontinent and Southeast Asia. Most of Egyptian native chickens were classified into the haplotype E1, which contains $63.9 \%$ of individuals followed by E4 (16.6\%), E5 (11.1\%), E2 (5.5\%) and E3 (2.7\%), respectively. These findings indicate that the maternal lineages was involved in the origin of domestic chicken in Egypt may have roots in Indian subcontinent and other Southeast Asia. The genetic information from this study will probably pave the way to further studies for evaluation, preservation and improvement of Egyptian native chickens as genetic resources in the future.
\end{abstract}

Key words: Egyptian chickens, genetic diversity, mtDNA

J. Poult. Sci., 51: 359-363, 2014

\section{Introduction}

Egypt located in the north of Africa, bordering the Mediterranean Sea, between Libya and the Gaza Strip, and the Red Sea north of Sudan, and includes the Asian Sinai Peninsula. Egypt has four main native chicken breeds, Fayoumi, Dandarawy, Balady and the Sinai strain, moreover, the native chickens are well adapted to adverse environmental conditions and show resistance to some local diseases such as Rous sarcoma virus and avian leucosis (Hosny, 2006). Therefore, the evaluation and preservation of Egyptian native chickens as genetic resources, is essential for its improvement in the future.

Recently, mitochondrial DNA (mtDNA) is one of the useful tools to know the genetic structures or their diversities (Muchadeyi et al., 2008). A number of studies have investigated the origin and dispersal of domestic chickens

Received: December 16, 2013, Accepted: March 3, 2014

Released Online Advance Publication: March 25, 2014

Correspondence: Dr. S. Okamoto, Laboratory of Animal Breeding and Genetics, Faculty of Agriculture, Kagoshima University, Korimoto 121-24, Kagoshima 890-0065, Japan.

(E-mail: chacha@agri.kagoshima-u.ac.jp) using mtDNA sequence data. Akishinonomiya et al. (1996) reported that existing domestic chickens originated from Gallus gallus gallus in Thailand and adjacent regions. Kanginakudru et al. (2008) found the evidence for domestication of Indian chickens, which were originated from Gallus gallus spadiceus, Gallus gallus gallus and Gallus gallus murghi. Islam and Nishibori (2012) also reported that native fowls in Bangladesh were strongly influenced from Gallus gallus murughi. The domestication of chickens was occurred in Southeast Asia, South China and Indian subcontinent (Liu et al., 2006; Oka et al., 2007). Some studies using mtDNA D-loop sequences have addressed the origin of African native chickens. Muchadeyi et al. (2008) observed two distinct haplogroups in Zimbabwe native chickens, which may be originated from Southeast Asia and the Indian subcontinent. Accordingly, Razafindraibe et al. (2008) observed two haplotypes in Madagascar native chicken originated from Indonesia and African continent or an introgression from commercial lines. On the other hand, a single haplogroup seems to be of Indian origin was observed in Nigeria native chickens (Adebambo et al., 2010). In addition, Mwacharo et al. (2011) analyzed partial mtDNA D-loop sequences in East Africa (Kenya, 
Ethiopia, Sudan and Uganda) native chickens, and revealed the existence of at least five genetically distinct mtDNA Dloop haplogroups, which were originated from south and southwest China and/or surrounding regions as well as Southeast Asia such as Myanmar and Thailand. An investigation using microsatellite markers reported the three groups of Egyptian chickens (Eltanany et al., 2011). Ramadan et al. (2011) compared the phylogenetic differentiation between two Egyptian chicken breeds with mtDNA D-loop region. However, there are few works to evaluate the genetic diversity on Egyptian native chickens using mtDNA sequences.

Therefore, the present study was undertaken to estimate the genetic diversity and origin of Egyptian native chickens as genetic resources in the future.

\section{Materials and Methods}

\section{Sampling}

A total of 36 Egyptian native chicken blood samples were collected from the preserving stations belong to Alazab Poultry Integrated Project, the Fayoum governorate, Egypt. To verify the genetic relationships of the study populations to Asiatic and other African chickens, 14 haplotypes from the GenBank were included in the analysis.

\section{PCR Amplification and Sequencing}

DNA extraction from whole blood samples was performed using standard phenol-chloroform extraction (Sambrook, 1989), which were stored at $-20^{\circ} \mathrm{C}$ until use. A 546-bp in the D-loop hypervariable region in mtDNA was amplified with the following primer forward: L16750 (5' -AGGACTACGGCTTGAAAAGC-3' ; Akishinonomiya et al., 1994) and reverse: H522 (5' -ATGTGCCTGACCGAGGAACCAG3'; Liu et al., 2006). The PCR reaction included of $100 \mathrm{ng}$ of template DNA, 4 pmol of each primers, 1x EX Taq buffer, $400 \mu \mathrm{mol}$ of dNTPs mixture and 1 unit of EX Taq HS polymerase (Takara, Otsu, Japan). The PCR was conducted at $94^{\circ} \mathrm{C}$ for $2 \mathrm{~min}$, followed by 30 cycles consisting of $1 \mathrm{~min}$ denaturation at $94^{\circ} \mathrm{C}, 1 \mathrm{~min}$ annealing at $60^{\circ} \mathrm{C}$ and $1 \mathrm{~min}$ extension at $72^{\circ} \mathrm{C}$, with final extension at $72^{\circ} \mathrm{C}$ for $7 \mathrm{~min}$ using a Gene Amp PCR System 9700 (Applied Biosystems Inc, Foster City, CA, USA). The PCR products were electrophoresed $(100 \mathrm{~V}, 40 \mathrm{~min})$ on $2 \%$ agarose gels, and purified with Viogene Gel/PCR DNA Isolation System GP1001 (Viogene BioTek Corp, Taipei, Taiwan). The DNA sequence analysis was performed with Big Dye Terminator cycle sequencing kit v.3.1 and ABI Prism 3500 genetic analyzer sequencer (Applied Biosystems Inc).

\section{Data Analysis}

Multiple alignment analysis for the mtDNA D-loop nucleotide sequence data was carried out using the Clastal X version 2.1 computer software (Larkin et al., 2007). The position and number of polymorphic sites and corresponding haplotypes were calculated using MEGA v5.2.1 (Molecular Evolutionary Genetic Analysis Version 5.2.1 (Tamura et al., 2011). Nucleotide diversity (Nei and Li, 1979) and haplotype diversity (Nei, 1987) were estimated using ARLEQUIN v.3.5.1.3 (Excoffier et al., 2010). A median joining network (Bandelt et al., 1999) was constructed using NETWORK 4.611 software (Fluxus technology Ltd.) to classify the haplotypes under the setting described by Cuc et al. (2011) into nine clades, following Liu et al. (2006), three clades, following Oka et al. (2007), and two clades, following Muchadeyi et al. (2008). The list of haplotypes used and the corresponding GenBank accession number are shown in Table 1.

\section{Results and Discussion}

\section{Genetic Diversity and Haplotype Distribution}

Sequences spanning the 546-bp in the D-loop hypervariable region in mtDNA were used for analysis. Out of 36 individuals, a total of 4 variable sites were identified (Fig. 1). No insertions or deletions were detected in the present

Table 1. Haplotype names and accession numbers of reference chicken mtDNA sequences from DNA databank were used in the present study

\begin{tabular}{|c|c|c|}
\hline Haplotype & GenBank accession No. & Reference \\
\hline E1 - E5 & & This study \\
\hline Liu_A1 & AB114069 & Liu et al. (2006) haplotype A1 \\
\hline Liu_B1 & AB007744 & Liu et al. (2006) haplotype B1 \\
\hline Liu_C1 & $\mathrm{AB} 114070$ & Liu et al. (2006) haplotype $\mathrm{C} 1$ \\
\hline Liu_D1 & AY588636 & Liu et al. (2006) haplotype D1 \\
\hline Liu_E1 & AB114076 & Liu et al. (2006) haplotype E1 \\
\hline Liu_F1 & AF512285 & Liu et al. (2006) haplotype F1 \\
\hline Liu_G1 & AF512288 & Liu et al. (2006) haplotype G1 \\
\hline Liu_H1 & D82904 & Liu et al. (2006) haplotype H1 \\
\hline Liu_I1 & AB009434 & Liu et al. (2006) haplotype I1 \\
\hline Oka_D6 & AB268535 & Oka et al. (2007) haplotype D6 \\
\hline Oka_G1 & AB268545 & Oka et al. (2007) haplotype G1 \\
\hline Oka_F1 & AB268543 & Oka et al. (2007) haplotype F1 \\
\hline $\mathrm{Z}_{-} \overline{\mathrm{A}} 1$ & AM746024 & Muchadeyi et al. (2008) haplotype A1 \\
\hline $\mathrm{Z}-\mathrm{C} 1$ & AM746040 & Muchadeyi et al. (2008) haplotype C1 \\
\hline
\end{tabular}




$\begin{array}{lllll} & 1 & 1 & 2 & 2 \\ & 4 & 5 & 0 & 9 \\ & 5 & 1 & 8 & 4 \\ \text { E1 } & \text { C } & \text { T } & \text { C } & \text { A } \\ \text { E2 } & . & . & . & \text { G } \\ \text { E3 } & . & . & \text { A } & \cdot \\ \text { E4 } & \text { A } & . & \cdot & . \\ \text { E5 } & . & \text { C } & . & .\end{array}$

Fig. 1. Variable sites for 5 haplotypes observed in the Egyptian native chicken populations. Dots indicate nucleotide positions identical to those of Haplotype E1. Numbers at the top refer to variable sites and correspond to the nucleotide positions of Haplotype E1.

sequences. In the present study, the haplotypic diversity within the Egyptian chickens was $0.5635 \pm 0.0845$ which was higher than those of African populations (Ethiopian 0.374, Sudanese 0.413 and Ugandan 0.322: Mwacharo et al., 2011) or (Nigerian 0.421: Adebambo et al., 2010). However, the value is lower than those of other African fowls (Kenyan 0.857: Mwacharo et al., 2011 or Zimbabwean 0.730: Muchadeyi et al., 2008) and also lower than some Asian fowls (Vietnamese 0.615 to 0.942: Cuc et al., 2011) or (Laotian 0.854: Kawabe et al., 2014). The nucleotide diversity within the Egyptian chicken was 0.00123 \pm 0.00108 , which was lower than other African and Asian fowls except Ugandan fowls (0.00096: Mwacharo et al., 2011). Therefore, these results indicate that Egyptian native chicken have moderate genetic diversity in African chicken populations.

\section{Network Analysis of Haplotypes}

The five haplotypes were clustered into one clade, observed in the Egyptian native chickens (Fig. 2). Most of Egyptian native chickens were classified in the haplotype E1, which contains 23 individuals $(63.9 \%)$ followed by E4 (6 individuals, $16.6 \%)$, E5 (4, 11.1\%), E2 (2, 5.5\%) and E3 (1, $2.7 \%$ ), respectively. All haplotypes in this study clustered mainly with one haplogroup (clade $\mathrm{C}$ obtained from Muchadeyi et al., 2008) was similar to Zimbabwean, Sudanese, Northwest European chickens and six purebred lines. The haplotype E1 in the present study is identical to the partial sequence of haplotype $\mathrm{C} 3$ (clade $\mathrm{C}$ from Muchadeyi et al., 2008), and haplotype E1 (clade E from Liu et al., 2006), which sequenced from the chickens of Europe, the Middle East (Iran, Azerbaijan and Turkmenistan), India, China (provinces adjacent to Yunnan, South East) and Japan. Whereas, the other quoted haplotypes were not detected with Egyptian chicken in the present study. Liu et al. (2006) stated that the maternal lineages associated with this clade could have originated from the Indian subcontinent. Oka et al. (2007) suggested that this clade originated in Southeast Asia and was first introduced to the Indian subcontinent before spreading to other regions. Previous reports (MacDonald and Edwards, 1993; Fuller et al., 2011; Mwacharo et al., 2013) suggested that, chickens may have first entered into Africa overland from the North area such as Egypt, and then dispersed into the South along the Nile valley to Nubia and after that in West Africa along the Sudano-Sahelian corridor. MacDonald and Edwards (1993) reported that chickens distributed into West Africa from the East African coast through the Sudano-Sahelian belt, occurred much later, those seems to be related to Indian Ocean trade networks. Liu et al. (2006) suggests that the introduction of the haplogroup E into the African continent was almost the consequence of a maritime introduction. Its arrival might have followed the Chinese maritime trading expeditions across the Indian Ocean (Duyvendak, 1939; Beaujard, 2005; Mwacharo et al., 2011). These findings indicate that the maternal lineages was involved in the origin of domestic chicken in Egypt may have roots in Indian subcontinent and other Southeast Asia. The genetic information from this study will probably pave the way to further studies for evaluation, preservation and improvement of Egyptian native chickens as genetic resources in the future.

\section{Acknowledgments}

We are grateful to Dr. Ahmed Radwan, the director of Alazab Poultry Integrated Project, the Fayoum governorate, Egypt, for his support to collect blood samples of the Egyptian native chickens. The author was also supported by a joint supervision mission from the Ministry of High Education, Cairo, Egypt. 


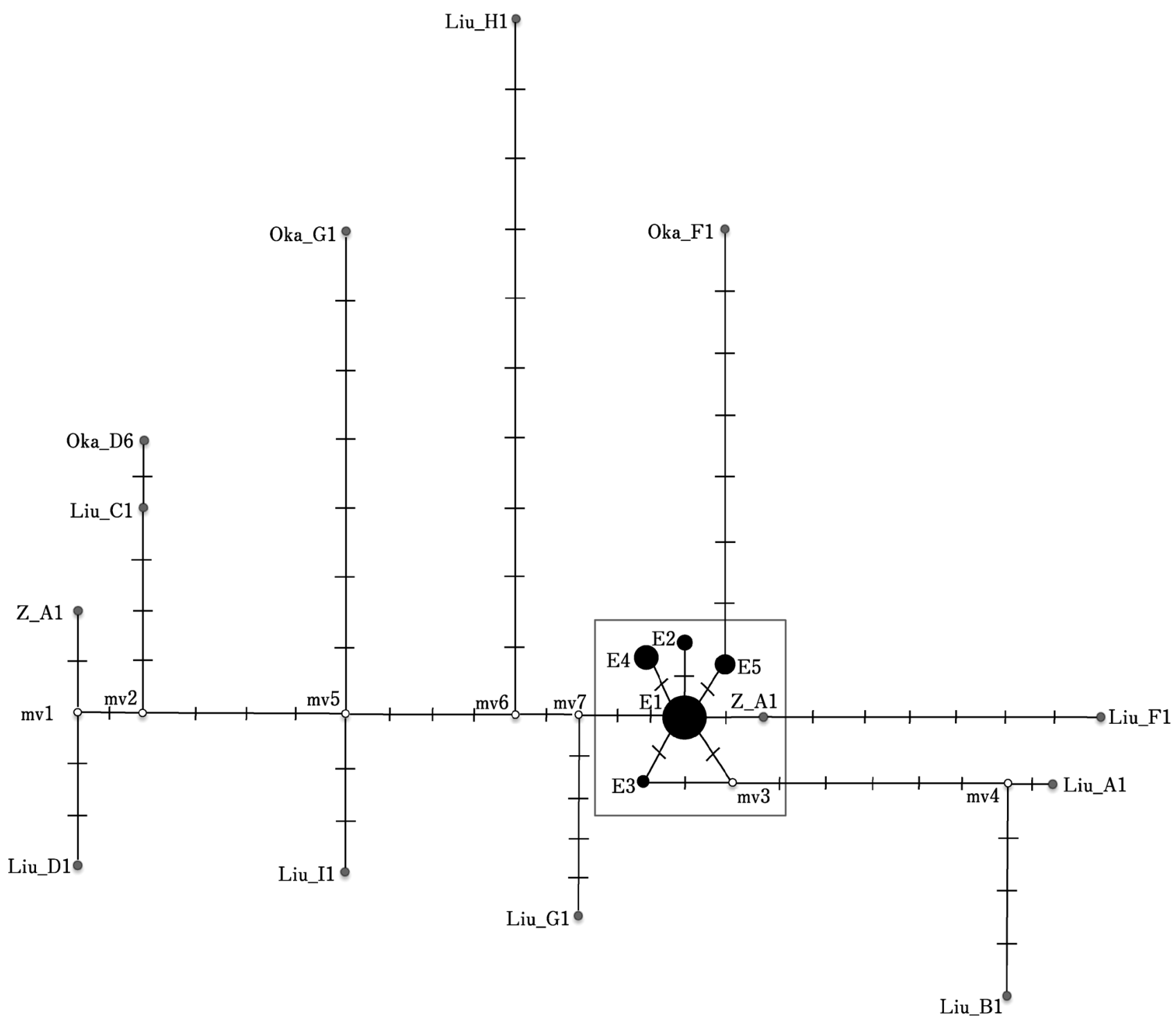

Fig. 2. Median network profile of the mtDNA D-loop haplotypes observed in the present study. Data merged with sequences of major haplotypes described from Liu et al. (2006), Oka et al. (2007) and Muchadeyi et al. (2008). The circle size corresponds to haplotype frequently. Empty circles are median vectors used in connecting haplotypes indirectly.

\section{References}

Adebambo AO, Mobegi VA, Mwacharo JM, Oladejo BM, Adewale RA, Ilori LO, Makanjuola BO, Afolayan O, Bjørnstad G, Jianlin $\mathrm{H}$ and Hanotte $\mathrm{O}$. Lack of phylogeographic structure in Nigerian village chickens revealed by mitochondrial DNA Dloop sequence analysis. International Journal of Poultry Science, 9: 503-507. 2010.

Akishinonomiya F, Miyake T, Sumi S, Takada M, Ohno S and Kondo N. One subspecies of the red jungle fowl (Gallus gallus gallus) suffices as the matriarchic ancestor of all domestic breeds. Proceedings of the National Academy of Sciences of the United States of America, 91: 12505-12509. 1994.

Akishinonomiya F, Miyake T, Takada M, Shingu R, Endo T, Gojobori T, Kondo N and Ohno S. Monophyletic origin and unique dispersal patterns of domestic fowls. Proceedings of the National Academy of Sciences of the United States of America, 93: 6792-6795. 1996.

Bandelt HJ, Forster P and Röhl A. Median-joining networks for inferring intraspecific phylogenies. Molecular Biology and Evolution, 16: 37-48. 1999.

Beaujard P. The Indian Ocean in Eurasian and African worldsystems before the sixteenth century. Journal of World History, 
16: 411-465. 2005.

Cuc NTK, Simianer H, Groeneveld LF and Weighend S. Multiple maternal lineages of Vietnamese local chickens inferred by mitochondrial D-loop sequences. Asian-Australian Journal of Animal Sciences, 24: 155-161. 2011.

Duyvendak JJL. The true dates of the Chinese maritime expeditions in the early fifteenth century. T'oung Pao, Second Series, 34: 341-413. 1939.

Eltanany M, Philipp U, Weigend S and Distl O. Genetic diversity of Egyptian chicken strains using 29 microsatellite markers. Animal Genetics, 42: 666-669. 2011.

Excoffier L and Lischer HEL. Arlequin suite ver 3.5: A new series of programs to perform population genetics analyses under Linux and Windows. Molecular Ecology Resources, 10: 564-567. 2010.

Fuller DQ, Boivin N, Hoogervorst T and Allaby R. Across the Indian Ocean: The prehistoric movement of plants and animals. Antiquity, 85: 544-558. 2011.

Hosny FA. The structure and importance of the commercial and village based poultry system in Egypt. In: Poultry Sector Country Review (Ed. by Food and Agricultural Organization of The United Nations). pp. 20-28. FAO. Rome. 2006.

Islam MA. and Nishibori M. Phylogenetic analysis of native chicken from Bangladesh and neighboring Asian countries based on complete sequence of mitochondrial DNA D-loop region. Journal of Poultry Science, 49: 237-244. 2012.

Kanginakudru S, Metta M, Jakati RD and Nagaraju J. Genetic evidence from Indian red jungle fowl corroborates multiple domestication of modern day chicken. BMC Evolutionary Biology, 8: 174. 2008.

Kawabe K, Worawut R, Taura S, Shimogiri T, Nishida T and Okamoto S. Genetic diversity of mtDNA D-loop polymorphism in Laotian native fowl populations. Asian-Australian Journal of Animal Sciences, 27: 19-23. 2014.

Larkin MA, Blackshields G, Brown NP, Chenna R, McGettigan PA, McWilliam H, Valentin F, Wallace IM, Wilm A, Loopez R, Thompson JD, Gibson TJ and Higgins DG. Clustal W and Clustal X version 2.0. Bioinformatics, 23: 2947-2948. 2007.

Liu YP, Wu GS, Yao YG, Miao YW, Luikart G, Baig M, BejaPereira A, Ding ZL, Palanichamy MG and Zhang YP. Multiple maternal origins of chickens: Out of the Asian jungles. Molecular Phylogenetics and Evolution, 38: 12-19. 2006.

MacDonald KC and Edwards DN. Chicken in Africa: The im- portance of QasrIbrim. Antiquity, 67: 584-590. 1993.

Muchadeyi FC, Eding H, Simianer H, Wollny CBA, Groeneveld E and Weigend S. Mitochondrial DNA D-loop sequences suggest a Southeast Asian and Indian origin of Zimbabwean village chickens. Animal Genetics, 39: 615-622. 2008.

Mwacharo JM, Bjørnstad G, Mobegi V, Nomura K, Hanada H, Amano $\mathrm{T}$, Jianlin $\mathrm{H}$ and Hanotte $\mathrm{O}$. Mitochondrial DNA reveals multiple introductions of domestic chicken in East Africa. Molecular Phylogenetics and Evolution, 58: 374-382. 2011.

Mwacharo JM, Bjørnstad G, Han JL and Hanotte O. The history of African village chickens: an archaeological and molecular perspective. African Archaeological Review, 30: 97-114. 2013.

Nei M and Li W. Mathematical model for studying genetic variation in terms of restriction endonucleases. Proceedings of the National Academy of Sciences of the United States of America, 76: 5269-5273. 1979.

Nei M. Molecular Evolutionary Genetics, Columbia University Press: New York, USA. 1987.

Oka T, Ino Y, Nomura K, Kawashima S, Kuwayama T, Hanada H, Amano T, Takada M, Takahata N, Hayashi $\mathrm{Y}$ and Akishinonomiya F. Analysis of mtDNA sequences shows Japanese native chickens have multiple origins. Animal Genetics, 38: 287-293. 2007.

Ramadan HAI, Galal A, Fathi MM, El Fiky SA and Yakoub HA. Characterization of two Egyptian native chicken breeds using genetic and immunological parameters. Biotechnology in Animal Husbandry, 27: 1-16. 2011.

Razafindraibe H, Mobegi VA, Ommeh SC, Rakotondravao J, Bjørnstad G, Hanotte O and Jianlin H. Mitochondrial DNA origin of indigenous Malagasy chicken: implications for a functional polymorphism at the $M x$ gene. Annals of the New York Academy of Sciences, 1149: 77-79. 2008.

Sambrook J, Fritsch EF and Maniatis T. Molecular Cloning: A Laboratory Manual. $2^{\text {nd }}$ ed, Cold Spring Laboratory Press. Cold Spring Harbor. New York. USA. 1989.

Tamura K, Peterson D, Peterson N, Stecher G, Nei M and Kumar S. MEGA5: Molecular evolutionary genetics analysis using maximum likelihood, molecular evolutionary distance, and maximum parsimony methods. Molecular Biology and Evolution, 28: 2731-2739. 2011. 